\title{
Disseminated Tumor Cell
}

National Cancer Institute

\section{Source}

National Cancer Institute. Disseminated Tumor Cell. NCI Thesaurus. Code C97750.

Metastatic tumor cells found singly or in small clusters in the tissues. 